\title{
Operational Risk Management in Islamic Banking; A System Thinking Approach
}

\author{
Muhammad Farhan ${ }^{1 *}$, Hassan Mobeen Alam ${ }^{2}$ \\ ${ }^{1} \mathrm{PhD}$ Scholar, Hailey College of Commerce, University of the Punjab, Lahore, Pakistan \\ ${ }^{2}$ Principal, Hailey College of Commerce, University of the Punjab, Lahore, Pakistan
}

\section{Keywords \\ Islamic Banking \\ Operational Risk \\ System Thinking \\ Risk Management}

Received: 24 October 2018

Accepted: 08 November 2018

\begin{abstract}
This research paper aims to explore the operational risk management structure of Pakistani Islamic banking system by developing a system dynamic model through a novel methodology called system thinking approach. This model has facilitated to understand the interrelationships between various characters of operational risk and its management. In order to develop the system dynamic model, this study has been divided into three stages. In the first stage, the researchers have developed an initial casual loop diagram on the basis of preliminary knowledge and understanding achieved through literature review on causal interconnections between various variables of operational risk management system. In the second stage, semi-structured face to face interviews have been conducted from risk managers to improve, confirm and add risk factors in the preliminary model. In the last stage, a refined system dynamic model has been developed based on interview data analysis. The model indicates that an escalation in the operational risk induces the Islamic banking institutions to proactively develop a framework to manage the operational risk as per the prudential regulations of the central bank. Therefore, the Islamic banking institutions take steps to manage the operational risk by giving training to their staff, making contingency plans, adopting advanced technology for Islamic banking, improving internal control system, confirming disciplined workplace environment and ensuring compliance with Sharī'ah and fiduciary responsibilities.
\end{abstract}

KAUJIE Classification: L31, L41, T4

JEL Classification: G21, G32

(C) 2018 JIBM. All rights reserved.

\section{INTRODUCTION}

An effective and balanced economic system without any financial crisis is the biggest challenge in front of today's world. An effort is in progress by the Muslims of twenty-first century to establish an economic system and financial institutions on the basis of Islamic

\footnotetext{
* Corresponding author: Muhammad Farhan
}

†Email: farhanlatif12@hotmail.com 
laws, principles and regulations. In an environment where the whole economic system is based on interest, it is very difficult and challenging task. However, risk sharing which is the base of Islamic financial system has appeared as a substitute to conventional financial system of risk transfer in the era of black swans, difficulties and complications, for a multipolar world (El Tiby, 2011; Mirakhor \& Smolo, 2014; Shaukat \& Mirakhor, 2017).

Islam is a rules-based system in which a setup of recommended procedures, regulations and principles directs the social, economic, political and legal structure of the society. Compliance with these principles and regulations renders the society a combination of collective support by demanding individuals to share the risks in life (Mirakhor \& Smolo, 2014). The main objective of Islamic finance is to form a stable financial system which fulfils the requirements of the consumers, institutions and the state; assists the real economy; and leads to equitable dissemination of wealth in the economy by evading prohibited (harām) actions, contracts and transactions (Saba, 2017).

Islamic banking industry is growing rapidly and with estimated assets crossing US\$ 2 trillion wrapping financial and non-financial institutions, capital markets, money markets and takäful in more than 90 countries in the world, including 50 Muslim countries and above 700 Islamic financial institutions all over the world (Saba, 2017). It is expected that by the year end 2022, the Islamic financial market size will touch US\$ 3.8 trillion (Maierbrugger, 2018). In some Islamic countries, the growth of Islamic banking is more than conventional banking. It is also gaining huge popularity in non-Islamic countries like England, South Africa, Singapore, Sri Lanka, USA, Germany, Australia and Luxembourg, etc. (Alawode, 2015). According to Islamic Finance Bulletin issued by College of Industrial Management (2016), global Islamic financial industry has grown $3.6 \%$ as compared to $1.5 \%$ of nonIslamic industry between 2011 and 2015. Growth of Islamic banking indicates that it is no longer limited to the Muslim world. As it is less risky by dint of its principles, ethical attributes are attracting non-Muslim world as an alternative of conventional banking (Saba, 2017).

Islamic banking in Pakistan is at its early stage. However, it is growing rapidly in this era of economic uncertainties and competition, hence, catching the interest of the researchers to throw light on the operational risk exposures confronted by Pakistani Islamic Banking Institutions (IBIs). Currently, five Islamic banks are operational in Pakistan along with sixteen traditional banks offering Islamic Banking services through 2,685 branches across Pakistan. By the end of June 2018, Islamic Banking obtained 12.9\% (Rs. 2,482 Billion) share of the total banking market with $14.8 \%$ (Rs. 2,033 Billion) portion of deposits in the whole banking sector of Pakistan. The profit of Islamic banking was recorded Rs.15 Billion at the end of second quarter of 2018, which was Rs.3 Billion more as compared to profit at the end of same quarter last year (State Bank of Pakistan, 2018).

All banking institutions have to face various risks such as currency risk, rate of return risk, commodity risk, credit risk, operational risk, reputational risk, legal risk and liquidity risk due to their nature of business. Islamic banking is exposed to not only the risks of conventional banking, but it also has its own unique risks because of its different asset class and liability structure (El Tiby, 2011; Hassan, 2009; Iqbal \& Mirakhor, 2011; Rahman, Tafri, \& 
Aljanadi, 2010; Schoon, 2016). The new types of risk exposures, which Islamic banking institutions have to face, are due to the requirement of compliance with the Shari' 'ah principles (El Tiby, 2011; Khan \& Ahmad, 2001). Furthermore, the nature of some risks faced by Islamic banking institutions is much different from their conventional peers because of the unique risk characteristics inherent in the Islamic modes of financing (Eid, 2012). Among all the risks faced by Islamic banking institutions, operational risk is the most important risk and its importance has increased significantly in the last few years (Dar, Azeem, \& Masood, 2013).

An operational risk is closely associated with an Islamic banking institution's daily business. As in the case of conventional banks, this will always be present in an Islamic banking institution's operations. Academia, practitioners and regulators are agreed to the point that effective risk management of operational risk is essential for the success and survival of the banks, either Islamic or conventional, and its importance is increasing over time, particularly after the recent crises and the recession (Rehman, Benamraoui, \& Dad, 2018). An effective risk management system not only minimizes the effects of risks on the performance of banks, but also safeguards the whole banking industry from any serious breakdown or crisis (Aebi, Sabato, \& Schmid, 2012; Akkizidis \& Khandelwal, 2007a; 2007b; Kao, Lin, Hsu, $\&$ Chen, 2011).

The Islamic banking institutions are advised by the State Bank of Pakistan to contemplate all risks disturbing their operations including the risk of loss due to poor internal controls, procedures, techniques, systems and people, or from outside events. They are also required to consider potential cause of losses due to non-compliance with Sharī'ah and fiduciary responsibilities. Furthermore, it is necessary for each and every Islamic bank to determine key risk indicators and apply effective controls pertaining to operational risk management like delegation of authority, segregation of responsibilities, code of conduct, annual mandatory leaves, customer dealing, succession planning, complaints management, staff compensation, recruitment and training, management information system and physical controls etc., irrespective of its size and complexity (State Bank of Pakistan, 2008).

This research paper aims to explore the risk management structure of Pakistani Islamic banking system regarding the operational risk by developing a System Dynamic Model (SDM) through a novel approach which is system thinking approach. Operational risks are the most crucial risks faced by Islamic banking institutions and it is vital to know the interrelationships between various characters of operational risks and their management. Therefore, this study uses system thinking approach to draw Causal Loop Diagram (CLD) in order to identify, understand and document the dynamic behavior of various operational risk management variables in the risk management system of Pakistani Islamic banking institutions; grasp various operational perspectives of the system and utilize the gained knowledge for making the system better.

As this paper aims to explore the operational risk management structure of IBIs in Pakistan; it is important to decide, what is the best way to achieve this objective? One way of describing the working of a system is to study the system through literature, confirm and modify it by integrating practical and theoretical approaches, incorporate changes and 
present this exploration in the shape of a traditional study. However, this study has used system thinking approach to visualize the working of a system through CLD, which graphically represents complete working of a complex system. This approach implies that base for understanding lies in construing interrelationships within the system. The interrelationships are the reason for behavioral patterns and events that we presume (Bellinger, 2004). This study has taken into account not only the full-fledged Islamic banks, but also the conventional banks with Islamic branches, which distinguishes this study from the most of others in the local context by presenting detailed visualization of complete system operating in Pakistan. Moreover, the systematic representation of operational risk management structure of IBIs in Pakistan could be helpful for all the stakeholders of this system, as this approach makes the system easy to understand.

\section{CONCEPTUAL FRAMEWORK}

\section{Operational Risk}

Operational risk in any Islamic banking institution may arise from its poor or abortive processes, people and systems, or due to external occurrences. Sharī'ah non-compliance risk and legal risk are considered to be part of the operational risk. However, reputational risk and strategic risk are not included in it. (Abdullah, Shahimi, \& Ismail, 2011; Dar et al., 2013; Islamic Financial Services Board, 2005; State Bank of Pakistan, 2008). The operational risk usually arises from the internal activities of the bank such as staff member's casualness, inadequate internal procedures and systems. However, various unpredictable and uncontrollable external events such as flood and terrorist's attack may also cause operational risk in any Islamic banking institution (Crouhy, Galai, \& Mark, 2006; Saunders \& Cornett, 2011).

According to Archer and Haroon (2012), operational risk in Islamic banking can be divided into following three types:

- Operational risk arising from different kinds of banking activities; it is similar for all banking institutions. However, operational risk may also arise from the contract drafting and execution of asset based nature of financing modes like murābahah, salam, istisnn $\bar{a}^{\natural}$ and ijärah which is specific for these products.

- Sharī'ah non-compliance risk taking place because of non-compliance with Sharī'ah rules and regulations, which may lead to loss of revenues and the reputation; or noncompliance with the fiduciary responsibilities as mudārib.

- Legal risk arising from banking operations or due to legal ambiguity in understanding and enforcing the Shari`'ah-compliant financial contracts.

As per the definition of operational risk in Islamic banking institutions, the following risks are also part of the operational risk.

\section{Sharī'ah Non-Compliance Risk}

The relationship between an Islamic bank and its customers is not only limited to an agent and principal, but it is also based on the trust and belief of the customers that their bank 
will comply with all the rules, principles and regulation given by Islamic Sharī'ah. This is basically the main difference that distinguishes Islamic banks from their conventional peers (DeLorenzo, 2007). However, if an Islamic bank fails to comply with the Sharī'ah rules and regulations as prescribed by the regulatory authority and its Sharí' ah advisors, it is exposed to Sharī'ah non-compliance risk (State Bank of Pakistan, 2008). It is responsibility of the Islamic banks to ensure that all the banking contracts from documentation to execution are fully in accordance to Shari 'ah rules and principles (Islamic Financial Services Board, 2005).

Non-compliance with Sharī'ah breaks the confidence and trust of the customers and adversely affects the reputation and creditworthiness of an Islamic bank. This situation may lead to excessive withdrawal by the customers, hence, triggering the liquidity crisis (Eid, 2012). At the moment, the Islamic banking is facing a big challenge with regard to reputation. So, to compete with their conventional peers in the competitive environments, the Islamic banks should have to be very careful in executing the banking transactions because any bad incident can damage the reputation of whole Islamic banking industry. Furthermore, not only the banking transactions but also the personal attitude and behavior of the banking staff members are important in this regard.

\section{Fiduciary Risk}

Fiduciary risk takes place when an Islamic bank fails to fulfil its fiduciary responsibilities. In other words, fiduciary risk arises when an Islamic banking institution is held legally liable for breaching the investment contract, either for non-compliance with Sharī'ah rules and principles or for mismanagement of the funds provided by its investors (Jackson-Moore, 2009). Fiduciary responsibility of an Islamic bank is to act in the best interests for its all stake holders. When actions of a bank deviate from these objectives, it is exposed to fiduciary risk (Eid, 2012). Fiduciary risk further exposes the bank to legal and regulatory consequences, reputational risk and withdrawal risk which ultimately leads to liquidity crisis for the bank.

\section{Legal Risk}

Legal and regulatory risks arise from not complying with legal and regulatory requirements by the banking institutions (Djojosugito, 2008). This risk may also arise due to violations, errors or negligence on the part of the bank to fulfil legal and regulatory requirements, procedures and/or ethical standards (Schroeck, 2002). Legal risk in Islamic banking may also be caused by inadequate legal framework; conflict of Sharí'ah rules and regulations with legal decisions; and conflict between Islamic laws and prevailing conventional laws (Ahmed \& Khan, 2007; Akkizidis \& Khandelwal, 2007a; 2007b). Legal risk can adversely affect the reputation of a bank which may lead to reduced business opportunities and liquidity problems (Crouhy et al., 2006; Sokolov, 2007).

The next section provides brief explanation of system thinking approach. 


\section{System Thinking Approach}

System thinking is basically a way to understand how things work in a systemic way. It is a way to seek pattern of behavior by going beyond the events, a perspective which looks for systematic interrelationships that are responsible for the behavioral patterns and events (Bellinger, 2004; Sherwood, 2002). This is a system which implies that base for understanding lies in construing interrelationships within the system. The interrelationships are the reason of behavioral patterns and events we presume (Bellinger, 2004). System thinking is a combination of three components: elements (characteristics), interconnections (the way these elements relate to each other), and a purpose (a function), where purpose is the most crucial part of the system (Meadows, 2008). Adoption of system thinking has considerably increased in various fields such as health (Kapp, Simoes, DeBiasi, \& Kravet, 2017; Leischow, et al., 2008; Peters, 2014), information technology (Ivanov, 1991; Jokonya, 2016), education (Boersma, Waarlo, \& Klaassen, 2011; Rodriguez, 2013; Shaked \& Schechter, 2017), infrastructure (Alasad, Motawa, \& Ougunlana, 2013) and business and management (Dutta, 2001; Jonker \& Karapetrovic, 2004; Rajagopal, 2012; Skarauskien, 2009).

System dynamics refer to comprehensive modelling approach which visually represents complex systems with the aim to develop in-depth understanding about interrelationships of different parts of the systems through building and rebuilding the system structure (Alasad et al., 2013; Sterman, 2001). It is a combination of philosophy, theory and methods needed to analyze systematic behaviours not only in business and management, but also in politics, health, engineering and economic behaviours (Hjorth \& Bagheri, 2006). This method has established the development of CLD, a powerful graphic tool to capture mental models. This qualitative model is dependent on feedback loops; exploration of these feedback loops can provide valuable intuitions into probable long-term behaviors (Moscardini \& Vlasova, 2003; Richmond, 1993). A CLD (CLD) is a combination of four components: the variables; the links between the variables; the signs of the links (which indicate about the interconnection of the variables); and sign of the loop (which indicates the type of behavior, system will produce). By connecting together various loops, we can form brief explanation about a specific problem (Lannon, 2018).

The first step in CLD is the identification of the variables (things, actions or feelings) that are important to the problem, where a variable is something that can change over time. The variables are connected through causal links (arrows) which display the relationship between them with polarities (Positive ' + ' and negative '-' signs). The positive $(+)$ sign shows that any variation in one variable induces the variation in other variable in the same course, while negative (-) sign indicates that any variation in one variable induces the change in other variable in the reverse direction (Alasad et al., 2013).

\section{METHODOLOGY}

This study has adopted inductive research approach to answer the research question by utilizing qualitative research strategy for the development of qualitative system dynamic 
model. Moreover, case study research design has been used by taking Pakistani Islamic banking system as a case. Hence, all Islamic Banking Institutions (IBIs) constitute population of this study. Moreover, the researchers adopted purposive sampling technique to collect the interview data from the risk managers of all selected banks. Purposive sampling technique is one of the most economical and time saving sampling technique, especially when the sources to collect the data are very limited that can effectively contribute for the research (Black, 2010). This sampling technique involves the researcher to make rational decisions regarding the respondents and research sites by providing the required information to answer the research questions (Saunders, Lewis, \& Thornhill, 2009, p. 237).

The researchers contacted and collected data through face to face semi-structured interviews from one senior risk manager of each selected bank. Semi-structured interviews contain some pre-formulated questions that assist to explain the unexplored areas. Such questions empower the interviewer to follow up on fresh leads of questions that may occur during the interview. In other words, there is no strict adherence to the pre-formulated questions in these interviews (Myers, 2009; Saunders, Lewis, \& Thornhill, 2012). So, semistructured interviews are useful as they enable the researcher to explore and understand problem under investigation in better way. As aim of this study is to examine the operational risk management structure of the Pakistani Islamic banking sector, the risk managers are the most relevant individuals for this study. They are not only the experts of the system, but can also productively add, validate and confirm the preliminary CLD. The respondents of the interviews were very senior bankers having, on average, more than fifteen years banking experience and more than eleven years risk management experience. The researchers selected senior risk managers because of their in-depth understanding relating to the risk management structure of their respective bank. These experts were very busy people; therefore, the researcher could not form an expert panel.

In order to develop system dynamic model, this study has been divided into three stages. Firstly, the researcher has developed an initial casual loop diagram on the basis of knowledge and understanding achieved through literature review on cause and effect relationship among the characters of operational risk management system. In the second stage, semistructured face to face interviews have been conducted from the senior risk managers to improve, authenticate and add in the CLD. Finally, a refined system dynamic model has been developed based on interview data analysis. This CLD provides a medium for articulating for our understanding regarding the dynamic and interconnected nature of the Pakistani operational risk management structure. This model also facilitates to gain deeper and specific understanding regarding various operational risk management practices of Pakistani Islamic banking system. This makes the system more expressive and implicit by using CLD rather than being invisible.

\section{DEVELOPMENT OF SYSTEM DYNAMIC MODEL}

\section{Preliminary CLD}

Keeping in mind the complex system of operational risk management in Islamic banking 
system in Pakistan this paper adopts system thinking as procedural approach to ascertain, comprehend and draw a chain of causality between different variables of operational risk and the risk management policies that are in practice. Therefore, this paper has used system dynamic model to draw a CLD for understanding the dynamic behavior of various operational risk management variables in the risk management system of the IBIs, grasping different operational perspectives of the system, identifying and documenting interconnections between various characters of the Islamic banking risk management system in Pakistan, and utilizing the gained knowledge to make the system better.

In this study, the use of system thinking approach is restricted only to the development of casual loop diagram to capture the existence of causal relationships among various variables of operational risk management in the Islamic banking institutions of Pakistan. In order to develop an improved CLD, the researchers firstly developed an initial CLD (Figure 1) on the basis of preliminary knowledge and understanding achieved through literature review on causal relationships among different variables of operational risk management in the Islamic banking system of Pakistan. Secondly, the researcher went for confirmation as well as productive advice through interviews regarding the construction of system dynamic model from the experts of the field to present an improved CLD (Figure 2).

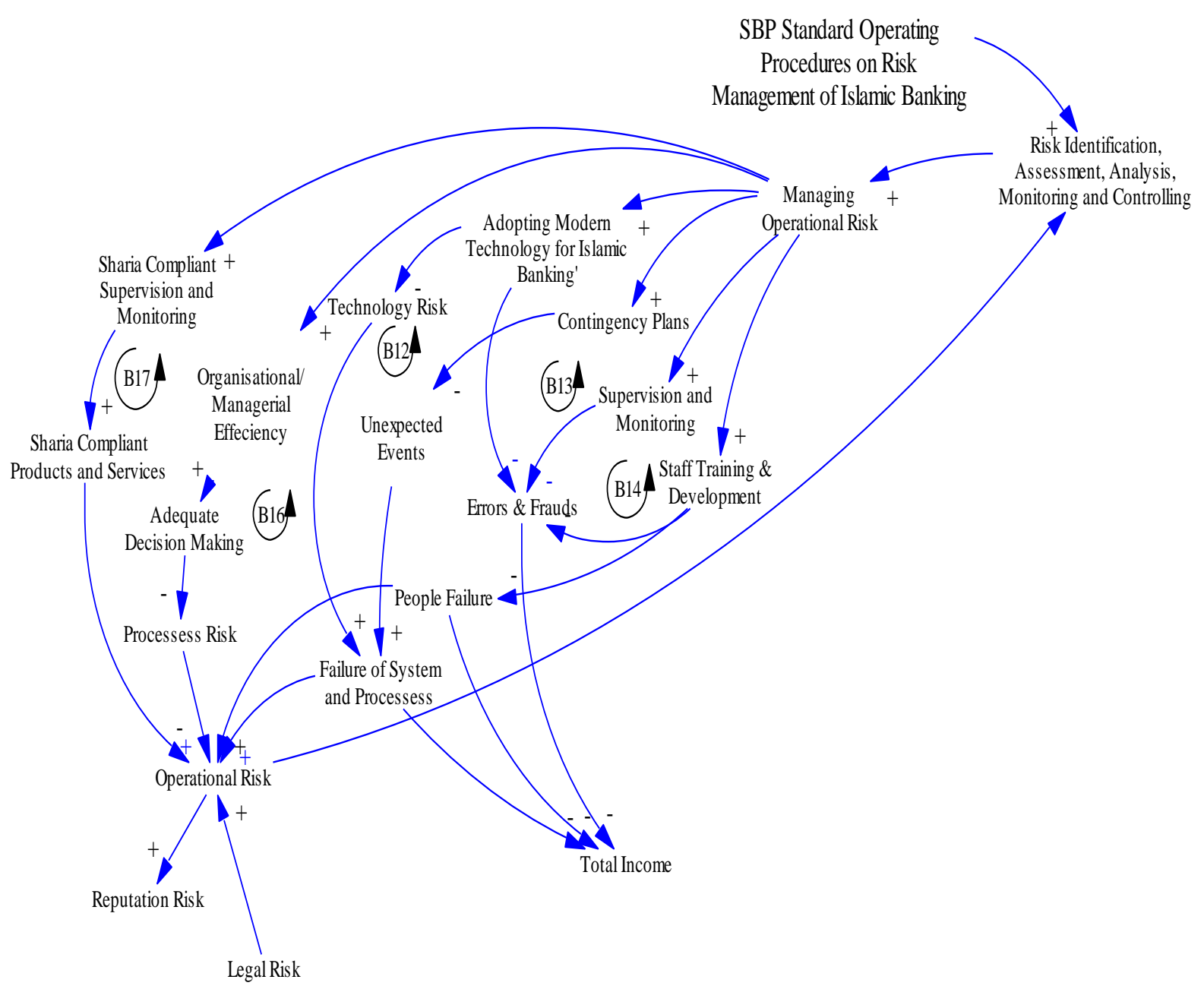

FIGURE 1. Preliminary CLD for managing operational risk 


\section{Validated CLD}

The development of qualitative system dynamic model comprises eliciting relative information from experts to authenticate the behaviour and system structure (Alasad et al., 2013). The guidelines obtained from the experts on the preliminary CLD have helped to refine the diagram. As a result a refined/validated CLD has been developed by the researcher. Managing Operational Risk (MOR) in Pakistan's Islamic Banking system is explained in the shape of a sub system CLD in figure II. This diagram consists of eight balancing feedback loops (B17, B18, B19, B20, B21, B22 and B23) and one reinforcing feedback loop (R5).

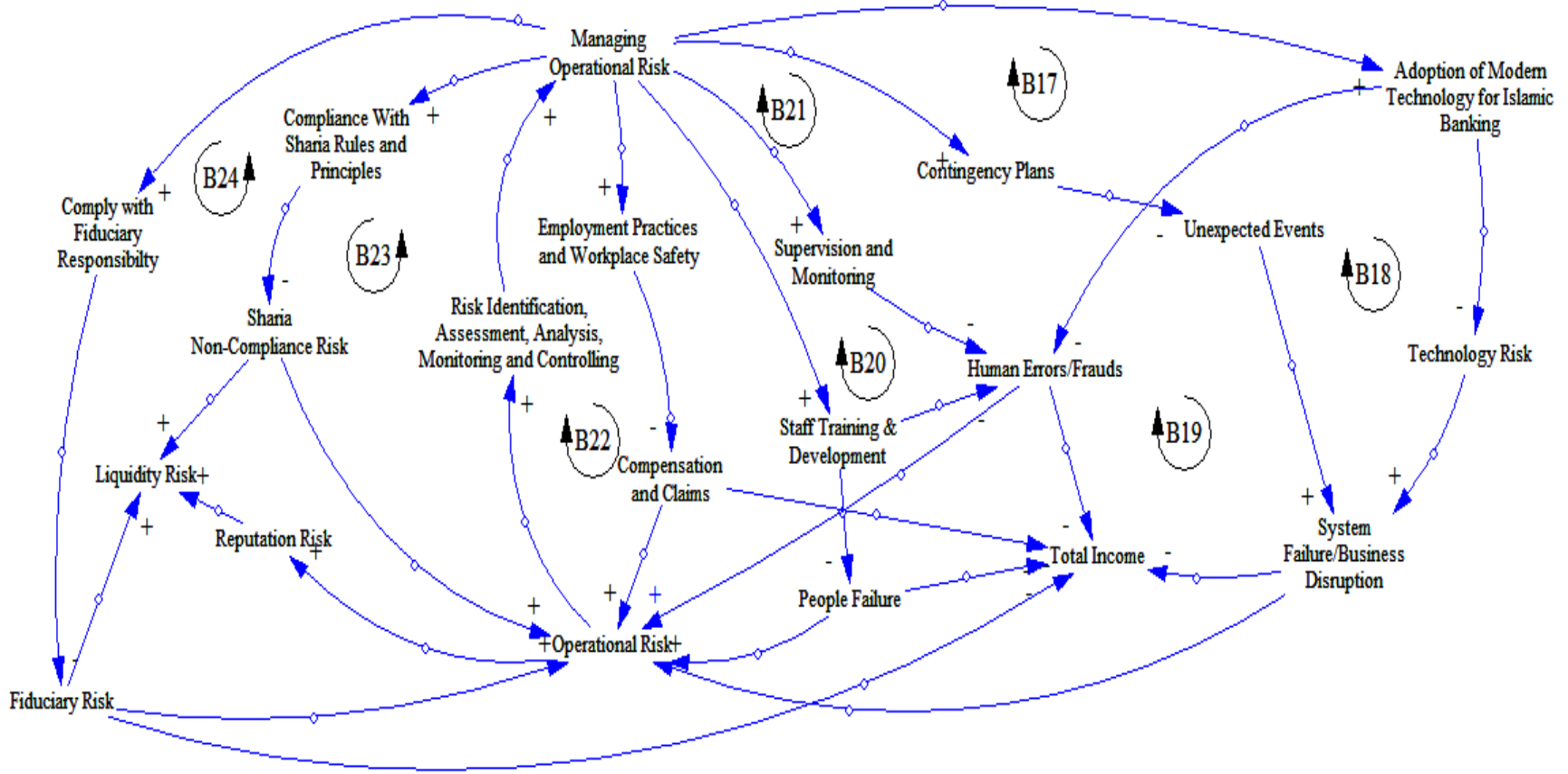

FIGURE 2. Validated CLD for managing operational risk

In the Figure 2 the B17 loop (Consisting of: MOR $\rightarrow$ Adoption of Advanced Technology $\rightarrow$ Human Errors/Frauds $\rightarrow$ Operational Risk $\rightarrow$ RIAAMC) indicates human errors and frauds, which have positive impact on operational risk. Hence, the IBIs in Pakistan spend huge amount to acquire sophisticated technology to reduce the possibilities of human errors and frauds so that operational risk could be minimized (Shafique, Hassan, \& Hussain, 2013). The loop B18 (Consisting of: MOR $\rightarrow$ Adoption of Advanced Technology $\rightarrow$ Technology Risk $\rightarrow$ System Failure/Business Disruption $\rightarrow$ Operational Risk $\rightarrow$ RIAAMC) specifies that adoption of sophisticated technology reduces the technology risk. However, where there is a technology, there is a problem. The technology can cause system failure/business disruption (Eid \& Asutay, 2016; Greuning \& Iqbal, 2008). Technology risk in Islamic banking is more complicated than in conventional banking because these banks have to invest more in advanced technology to make their system tailored specifically for Islamic banking as systems of conventional banks may not be appropriate for Islamic banks (Brown, Hassan, \& Skully, 2007; Eid \& Asutay, 2016). So, the banks make huge investment in advances technology to increase the efficacy of their information technology, in order to not only make it competitive for Sharī 'ah compliant Islamic banking, but also to reduce human errors/frauds, system failures, data hacking, virus attacks and network failure (Eid, 2012). 
The B19 loop (Consisting of: MOR $\rightarrow$ Contingency Plans $\rightarrow$ Unexpected Events $\rightarrow$ System Failure/Business Disruption $\rightarrow$ Operational Risk $\rightarrow$ RIAAMC) indicates that unexpected events like terrorism, earthquakes, floods, robbery and forgery etc. can also expose the banks to operational risk (Akkizidis \& Khandelwal, 2007a, 2007b). So, the Islamic banking institutions in Pakistan make contingency plans to resume the business operations efficiently in case of any unexpected event.

The B20 loop (Consisting of: MOR $\rightarrow$ Staff Training \& Development $\rightarrow$ People Failure $\rightarrow$ Operational Risk $\rightarrow$ RIAAMC) shows that people failure is also a cause of operational risk in Islamic banking which is minimized by providing training to the staff (Mahlknecht, 2009). Islamic banking institutions in Pakistan organize training and development programs for their staff to make them more effective and efficient in performing banking transactions and to make them capable for dealing with Sharī'ah-compliant financial activities. The B21 loop (Consisting of: MOR $\rightarrow$ Supervision and Monitoring $\rightarrow$ Human Errors/Frauds $\rightarrow$ Operational Risk $\rightarrow$ RIAAMC) indicates that more efficient the supervision and monitoring mechanism an Islamic bank has, the less human errors and frauds would take place (Fayyaz, 2006). A better internal control system also contributes in the total income of the banks.

The B22 loop (Consisting of: Employment Practices and Workplace Safety $\rightarrow$ Compensation and claims $\rightarrow$ Operational Risk $\rightarrow$ RIAAMC) indicates that inadequate work place safety or employment practices can expose banks to compensation and claims, which ultimately affects bank's profitability. The IBIs in Pakistan have a strong mechanism which addresses swiftly to any issue relating to work discipline, employment practices and workplace environment.

The relationship between the Islamic banking customers and Islamic banks is not limited to agent and principal; it is founded on the trust that Islamic banking institution will respect its customer's desire to completely observe Sharī'ah principles (Wilson, 2002). If a bank does not comply with Shari' ah, it breaks the trust of its customers and can severely damage its reputation which can lead it to liquidity problems. The B23 loop (Consisting of: MOR $\rightarrow$ Comply with Sharī'ah Rules and Principles $\rightarrow$ Sharī'ah Non-Compliance Risk $\rightarrow$ Operational Risk $\rightarrow$ RIAAMC) indicates that sensitivity of being Shari' ah compliant induces the risk management division of Islamic banks to make a mechanism that implements Shari' ah compliant products, services and operations as per the expectations of their customers. This loop further indicates that any non-Sharī'ah compliant activity may expose the banks to liquidity risk.

Islamic Banking Institutions are expected to act in the best interest of its stakeholders by complying with their fiduciary responsibility. Non-Compliance with the fiduciary responsibilities exposes the banks to fiduciary risk (Jackson-Moore, 2009). The B24 loop (Consisting of: Managing Operational Risk $\rightarrow$ Comply with Fiduciary Responsibility $\rightarrow$ Fiduciary Risk $\rightarrow$ Operational Risk $\rightarrow$ RIAAMC) explains that as per the prudential regulations issued by the SBP, the Islamic banking institutions perform in accordance with their fiduciary duties. This leads the banks to act with due care while handling the funds of their depositors and share profit and loss in accordance with their agency and fiduciary responsibilities. 
The R5 reinforce feedback loop (Consisting of: Total Income $\rightarrow$ Adoption of Advance Technology $\rightarrow$ Technology Risk $\rightarrow$ System Failure/Business Disruption) states that when there is an increase in bank's income, it induces the banks to spend more on advanced technology to counter the technology risk. Reduction in technology risk also smooths the business operations of the banks and reduces the chances of system failure. Consequently, it has positive influence on the total income of the banks, and vice versa (Brown et al., 2007).

Collectively Figure 2 indicates that an escalation in the operational risk induces the Islamic banking institutions to proactively take steps for managing operational risk as per the prudential regulations of State Bank of Pakistan. The Figure also indicates that operational risk takes place due to non-compliance with Sharī'ah and fiduciary responsibilities, failed systems, people and processes (Shafique et al., 2013). Therefore, the Islamic banking institutions take steps to manage the operational risk by giving training to their staff, making contingency plans, adopting advanced technology for Islamic banking, improving internal control systems, confirming disciplined workplace environment and ensuring compliance with Sharí'ah and fiduciary responsibilities (Abdullah et al., 2011; Shafique et al., 2013; Wahyudi, Rosmanita, Prasetyo, \& Putri, 2015). So, this study adds to the current body of knowledge by explaining operational risk management through a comprehensive modelling approach which visually represents this complex system, with the aim to develop in-depth understanding about cause and effect relationships of different variables of operational risk management by building and rebuilding system structure.

\section{CONCLUSION}

The State Bank of Pakistan (2008) provided guidelines, to ensure the presence of efficient risk management framework in the Islamic banking institutions of Pakistan (State Bank of Pakistan, 2008). Over the last decade, Islamic banking is expanding in Pakistan and creating more challenges for the banks to counter the potential operational risk exposures. The validated final system dynamic model demonstrates that Islamic banking institutions have formulated a comprehensive plan of action for identifying, assessing, understanding, analyzing, monitoring and controlling operational risk exposures to avoid any potential loss. The model also indicates that the IBIs in Pakistan have developed efficient mechanism to counter various risks under the guidelines provided by the regulatory authority which supports the homogeneity assumption of institutional theory (Collier \& Woods, 2011; DiMaggio \& Powell, 1983). This qualitative model provides helpful and useful insights for managers, scholars, shareholders, policy makers and regulators to understand the operational risk management behavior of Islamic banking system in Pakistan. Furthermore, this model also provides support to the Board of Directors and senior management of not only the banks in Pakistan, but also to the Islamic banks all over the globe for designing a comprehensive, effective and efficient operational risk management framework by overcoming any deficiency in their existing system. It is finally concluded that while managing operational risk, Islamic banking institutions in Pakistani are not throwing caution to the wind, but they are playing it safe. 


\section{REFERENCES}

Abdullah, M., Shahimi, S., \& Ismail, A. G. (2011). Operational risk in Islamic banks: Examination of issues. Qualitative Research in Financial Markets, 3(2), 131-151. doi: https://doi.org/10.1108/17554171111155366

Aebi, V., Sabato, G., \& Schmid, M. (2012). Risk management, corporate governance, and bank performance in the financial crisis. Journal of Banking $\mathcal{E}$ Finance, 36(12), 3213-3226. doi: https://doi.org/10.1016/j.jbankfin.2011.10.020

Ahmed, H., \& Khan, T. (2007). 10 risk management in Islamic banking. Handbook of Islamic banking. Cheltenham, UK: Edward Elgar Publishing.

Akkizidis, I., \& Khandelwal, S. K. (2007a). Financial risk management for Islamic banking and finance. London, UK: Palgrave Macmillan.

Akkizidis, I., \& Khandelwal, S. K. (2007b). Credit Risks in Islamic Finance. In I. Akkizidis \& S. K. Khandelwal (Eds.), Financial Risk Management for Islamic Banking and Finance (pp. 109-147). London, UK: Palgrave Macmillan.

Alasad, R., Motawa, I., \& Ougunlana, S. (2013). A system dynamics-based model for demand forecasting in PPP infrastructure projects-A case of toll roads. Organization, Technology \& Management in Construction: An International Journal, 5(Special), 791798. doi: https://doi.org/10.5592/otmcj.2013.3.4

Alawode, A. A. (2015). Islamic finance. Retrieved from https://bit.ly/2qdN8fp

Archer, S., \& Haron, A. (2012). Operational Risk Exposures of Islamic Banks. In S. Archer \& R. A. A. Karim (Eds.), Islamic Finance: The New Regulatory Challenge. Singapore: John Wiley \& Sons. doi: https://doi.org/10.1002/9781118390443.ch6

Bellinger, G. (2004). Systems thinking an operational perspective of the universe. Retrieved from https://bit.ly/2U99OZq

Boersma, K., Waarlo, A. J., \& Klaassen, K. (2011). The feasibility of systems thinking in biology education. Journal of Biological Education, 45(4), 190-197.

doi: https://doi.org/10.1080/00219266.2011.627139

Brown, K., Hassan, M. K., \& Skully, M. (2007). Operational efficiency and performance of Islamic banks. In Handbook of Islamic banking. Cheltenham, UK: Edward Elgar Publishing.

College of Industrial Management. (2016). Islamic finance bulletin. Center of Research Excellence for Islamic Banking and Finance. Retrieved from https://bit.ly/2GOsLxJ

Collier, P. M., \& Woods, M. (2011). A comparison of the local authority adoption of risk management in England and Australia. Australian Accounting Review, 21(2), 111-123. doi: https://doi.org/10.1111/j.1835-2561.2011.00126.x

Crouhy, M., Galai, D., \& Mark, R. (2006). The essentials of risk management. New York, NY: McGraw-Hill.

Dar, M. R., Azeem, M., \& Masood, D. O. (2013). Operational risk management, risk management approaches, and risk mitigation techniques: Challenges faced by Islamic financial services. Journal of Business and Management, 11(2), 72-79.

DeLorenzo, Y. T. (2007). Sharī'ah compliance risk. Chicago Journal of International Law, 7(2), 397-408. 
DiMaggio, P. J., \& Powell, W. W. (1983). The iron cage revisited: Institutional isomorphism and collective rationality in organizational fields. American Sociological Review, 48(2), 147-160. doi: https://doi.org/10.2307/2095101

Djojosugito, R. (2008). Mitigating legal risk in Islamic banking operations. Humanomics, 24(2), 110-121. doi: https://doi.org/10.1108/08288660810876822

Dutta, A. (2001). Business planning for network services: A systems thinking approach. Information Systems Research, 12(3), 260-283.

doi: https://doi.org/10.1287/isre.12.3.260.9713

Eid, W. (2012). Mapping the risks and risk management practices in Islamic banking (Doctoral dissertation). Durham University, Durham, UK.

Eid, W. K., \& Asutay, M. (2016). Mapping the risks and risk management practices in Islamic banking. New York, NY: John Wiley \& Sons.

El Tiby, A. M. (2011). Islamic banking: How to manage risk and improve profitability. Hoboken, NJ: Wiley.

Fayyaz, A., (2006). Managing risk in financial sector. In M. S. Umer (Ed.), Managing risk in financial sector. Karachi, Pakistan: The Institute of Bankers Pakistan.

Greuning, H. V., \& Iqbal, Z. (2008). Risk analysis for Islamic banks. Washington, DC, WA: World Bank.

Hassan, A. (2009). Risk management practices of Islamic banks of Brunei Darussalam. The Journal of Risk Finance, 10(1), 23-37.

doi: https://doi.org/10.1108/15265940910924472

Hjorth, P., \& Bagheri, A. (2006). Navigating towards sustainable development: A system dynamics approach. Futures, 38(1), 74-92.

doi: https://doi.org/10.1016/j.futures.2005.04.005

Iqbal, Z., \& Mirakhor, A. (2011). An introduction to Islamic finance: Theory and practice. Singapore: John Wiley \& Sons. doi: https://doi.org/10.1002/9781118390474

Islamic Financial Services Board. (2005). Guiding principles of risk management for institutions (other than insurance institutions) offering only Islamic financial services. Retrieved from https://bit.ly/2EvcRWl

Ivanov, K. (1991). Critical systems thinking and information technology: Some summary reflections, doubts, and hopes through critical thinking critically considered, and through hypersystems. Journal of Applied Systems Analysis, 18, 39-55.

Jackson-Moore, E. (2009). The international handbook of Islamic banking and finance. Tunbridge Wells, UK: Global Professional Pub.

Jokonya, O. (2016). Towards a critical systems thinking approach during IT adoption in organisations. Procedia Computer Science, 100, 856-864.

doi: https://doi.org/10.1016/j.procs.2016.09.235

Jonker, J., \& Karapetrovic, S. (2004). Systems thinking for the integration of management systems. Business Process Management Journal, 10(6), 608-615. doi: https://doi.org/10.1108/14637150410567839

Kao, M. C., Lin, C. Y., Hsu, P. P., \& Chen, Y. H. (2011). Impact of the financial crisis and risk management on performance of financial holding companies in Taiwan. World Academy of Science, Engineering and Technology, 74, 466-470. 
Kapp, J. M., Simoes, E. J., DeBiasi, A., \& Kravet, S. J. (2017). A conceptual framework for a systems thinking approach to US population health. Systems Research and Behavioral Science, 34(6), 686-698. doi: https://doi.org/10.1002/sres.2420

Khan, T., \& Ahmad, H. (2001). Risk management: An analysis of issues in Islamic financial Industry (Occasional paper no. 5). Islamic Development Bank, Islamic Research and Training Institute, Jeddah, Saudi Arabia.

Lannon, C. (2018). Causal loop construction: The basics. Retrieved from https://bit.ly/2Xq0nqm

Leischow, S. J., Best, A., Trochim, W. M., Clark, P. I., Gallagher, R. S., Marcus, S. E., \& Matthews, E. (2008). Systems thinking to improve the public's health. American Journal of Preventive Medicine, 35(2), S196-S203.

doi: https://doi.org/10.1016/j.amepre.2008.05.014

Mahlknecht, M. (2009). Islamic capital markets and risk management: Global market trends and issues. Lodon, UK: Risk Books.

Maierbrugger, A. (2018). Islamic finance assets seen at \$ 3.8tn by 2022. Retrieved from https://bit.ly/2NsAx0y

Mirakhor, A., \& Smolo, E. (2014). Epistemological foundation of finance: Islamic and conventional. Islamic Banking and Finance Review, 1(1), 01-24

Moscardini, A., \& Vlasova, T. (2003). The introduction of systems thinking into the economic curricula of Ukraine. Paper presented at the 21st International Conference of the Systems Dynamics Society, New York, NY.

Myers, M. D. (2009). Qualitative research in business and management. Los Angeles, CA: SAGE.

Peters, D. H. (2014). The application of systems thinking in health: Why use systems thinking? Health Research Policy and Systems, 12(1), 1-6. doi: https://doi.org/10.1186/14784505-12-51

Rahman, R. A., Tafri, F. H., \& AlJanadi, Y. (2010). Instruments and risks in Islamic financial institutions. Malaysian Accounting Review, 9(2), 11-21.

Rajagopal. (2012). Role of systems thinking in developing marketing strategy: Some conceptual insights. Journal of Transnational Management, 17(4), 258-276. doi: https://doi.org/10.1080/15475778.2012.732891

Rehman, A. A., Benamraoui, A., \& Dad, A. M. (2018). A comparative study of Islamic and conventional banks' risk management practices: Empirical evidence from Pakistan. Journal of Banking Regulation, 19(3), 1-14. doi: https://doi.org/10.1057/s41261-0170046-Z

Richmond, B. (1993). Systems thinking: Critical thinking skills for the 1990s and beyond. System Dynamics Review, 9(2), 113-133. doi: https://doi.org/10.1002/sdr.4260090203

Rodriguez, V. (2013). The potential of systems thinking in teacher reform as theorized for the teaching brain framework. Mind, Brain, and Education, 7(2), 77-85. doi: https://doi.org/10.1111/mbe.12013

Saba, I. (2017). Islamic fnance-local and global status. In Developments in Islamic fnance. Basingstoke, UK: Palgrave Macmillan. doi: https://doi.org/10.1007/978-3-319-593425_1 
Saunders, A., \& Cornett, M. M. (2011). Financial institutions management: Risk management approach. Singapore: McGraw-Hill.

Saunders, M. N. K., Lewis, P., \& Thornhill, A. (2009). Research methods for business students (5th ed). New York, NY: Prentice Hall.

Saunders, M., Lewis, P., \& Thornhill, A. (2012). Research methods for business students. Harlow, UK: Pearson.

Schoon, N. (2016). Modern Islamic banking: Products and processes in practice. West Sussex, UK: John Wiley \& Sons. doi: https://doi.org/10.1002/9781119234708

Schroeck, G. (2002). Risk management and value creation in financial institutions (Vol. 155). New York, NY: John Wiley \& Sons.

Shafique, O., Hussain, N., \& Hassan, M. T. (2013). Differences in the risk management practices of Islamic versus conventional financial institutions in Pakistan: An empirical study. The Journal of Risk Finance, 14(2), 179-196.

doi: https://doi.org/10.1108/15265941311301206

Shaked, H., \& Schechter, C. (2017). Systems thinking among school middle leaders. Educational Management Administration \& Leadership, 45(4), 699-718.

doi: https://doi.org/10.1177/1741143215617949

Shaukat, M., \& Mirakhor, A. (2017). Islamic Finance, in the age of black swans and complexities, for a multipolar world. In Developments in Islamic Finance (pp. 147176). Basingstoke, UK: Palgrave Macmillan. doi: https://doi.org/10.1007/978-3-31959342-5_7

Sherwood, D. (2002). Seeing the Forest for the Trees: A Manager's Guide to Applying Systems Thinking. London, UK: Nicholas Brealey.

Skarauskien, A. (2009). Systems thinking as a competence in the leadership paradigm. Management Theory and Studies for Rural Business and Infrastructure Development, 16(1), 97-105.

Sokolov, D. (2007). E-banking: Risk management practices of the Estonian banks (Working paper no. 156). Tallinn University of Technology, Tallinn, Estonia.

State Bank of Pakistan. (2008). Risk management guidelines for Islamic banking institutions. Karachi, Pakistan: State Bank of Pakistan.

State Bank of Pakistan. (2018). Islamic banking bulletin. Karachi, Pakistan: State Bank of Pakistan.

Sterman, J. D. (2001). System dynamics modeling: Tools for learning in a complex world. California Management Review, 43(4), 8-25. doi: https://doi.org/10.2307/41166098

Wahyudi, I., Rosmanita, F., Prasetyo, M. B., \& Putri, N. I. S. (2015). Risk management for Islamic banks: Recent developments from Asia and the Middle East. Singapore: John Wiley \& Sons. doi: https://doi.org/10.1002/9781118809211 